\title{
THE INFLUENCE OF CLIMATIC AND SOCIOECONOMIC FACTORS ON THE OCCURRENCE OF ALLERGIC CONJUNCTIVITIS AMONGST PRIMARY SCHOOL PUPILS IN OWERRI URBAN, NIGERIA
}

\author{
BY \\ AHUAMA, O. C. AND EMEREOLE, C. G. \\ DEPARTMENT OF OPTOMETRY, ABIA STATE UNIVERSITY \\ UTURU, ABIA STATE, NIGERIA \\ Email: drahuama@yahoo.com \\ *Corresponding author
}

\begin{abstract}
This study investigated some aspects of climatic and socioeconomic factors, which may influence the occurrence of allergic conjunctivitis among primary school pupils. A sample population of 150 pupils aged 5-15 years was randomly selected from different schools. The subjects were drawn from pupils of various classes and socioeconomic background. Questionnaire and clinical examination were used. The result revealed that climatic factor influences the occurrence of allergic conjunctivitis, $48.9 \%$ during harmattan season and $26 \%$ during rainy season. Occurrence in females was $59.3 \%$ compared to $32 \%$ in males. Pupils of the parents who were artisans had 52\% while those whose parents were professionals had $18.2 \%$. Pupils within the age of $9-12$ had $67.9 \%$, while the age group 13-15 had $13.9 \%$. Clinical sign on the conjunctiva only were seen on $67.9 \%$ of the pupils while $1.4 \%$ had clinical sign on the conjunctiva, eyelid and cornea.
\end{abstract}

KEYWORDS: Climatic factor, Socioeconomic factor, Pupils, Allergic conjunctivitis.

\section{INTRODUCTION}

The concept of illness is an interaction between external factors and internal capacity for resistance of an organism in question. In the same vain, allergy has been defined as an altered or exaggerated susceptibility to various foreign substances or physical agents, which are harmless to great majority of individuals; otherwise it is sensitivity or intolerance which many people find harmless ${ }^{1}$

Randolph and Moss ${ }^{2}$ has defined allergy as a condition of unusually sensitive to something eaten, breathed in, or touched in a way that causes pain or suffering. It could be as a result of an altered reactivity of an animal following exposure to a foreign antigen, including immunity and hypersensitivity. Gold and Peacock ${ }^{3}$ restricted allergy to hypersensitivity, which may be associated with the development of immune response to foreign substance.

Theodore ${ }^{4}$ classified ocular allergies into three categories, namely immediate anaphylactic response to pollen, inhalants, animal protein or food and delayed response (24-48 hours) due to microbial infection, drugs, cosmetics and other chemicals. These lead to different forms of conjunctivitis including catarrh and phlyctenular which are sight threatening. Muir ${ }^{5}$ opined that allergy could be explained solely in terms of immunologic theory, which can affect any part of the body, even the conjunctiva.

Allergic conjunctivitis is the result of antigenantibody reaction in the conjunctiva leading to redness and swelling ${ }^{6,7}$. An antigen may either be endogenous or exogenous ${ }^{8}$.

Though allergic conjunctivitis is noncontagious in itself but it imposes emotional disturbance and anxiety to the sufferer. Allergic conjunctivitis is usually characterized by sudden hyperemia, edema of conjunctiva, photophobia, sneezing, nasal congestion, blurring of vision, intense irritation, profuse tearing, slightly raised round nodules in the bulbar conjunctiva, itching, thread-like (stringy) mucous discharge, hyperemia and lid swelling ${ }^{9,10 .}$

In case of neglect and mismanagement by use of herbs, urine to the eye, it may lead to blindness and its attendant socio-economic consequences. Epidemiologically, conjunctivitis presents a lot of public health problems among the general population?.

The objective of this study is to identify the relationship between allergic conjunctivitis and climatic and socioeconomic factors in an urban setting such as Owerri in Imo State of Nigeria.

\section{MATERIALS AND METHODS}

The study population of 150 pupils of either sex was drawn from two primary schools in Owerri Urban, Imo State, Nigeria. The pupils were aged 5- 
15years. Seventy five (75) pupils were chosen from each school. The children came from parents/guardians of different socioeconomic background. The pupils were separated into various classes and then chosen by random sampling.

The subjects underwent visual acuity (VA) test, external and internal eye examination using standard Optometry procedures. The questionnaire was converted to oral interviews by the researchers; since subjects were children they could not all write their desired responses.

The questionnaire contains 4 parts: personal data, medical history particularly on allergies, dietary habit and social history of the pupil. The results obtained were analyzed using tables, and percentages.

\section{RESULTS}

Considering the occurrence of allergic conjunctivitis by gender, females had higher number of $89(59.3 \%)$, compared to males 48 $(32 \%)$ as shown in table 1 . Occurrence of allergic conjunctivitis was high during harmattan season, 67 (48.9\%), non-seasonal had $44(32.1 \%)$ while rainy season had the least occurrence $19(26 \%)$ as shown in table 2.

Table 3 showed that majority of the pupils 93 (67.9\%) had clinical sign on the conjunctiva only, compared to $42(30.7 \%)$ that had clinical sign the conjunctiva and eyelid, while $2(1.4 \%)$ had clinical sign on the conjunctiva, eyelid and cornea. Pupils within the age of 9-12 had the highest number of allergic conjunctivitis of 93 (67.9\%), followed by those within the age group of 5-8, 25(18.2\%) while age group 13-15 had the least number of 19 $(13.9 \%)$ as shown in table 4 . In considering the occupational status of parents of the pupils, those whose parents were artisans had the highest number of $77(56.2 \%)$ followed by civil servants $35(25.6 \%)$ while professionals had 25 (18.2\%; see table 5).

\section{DISCUSSION}

The climate, culture and occupation of inhabitants of any community have significant impact on the incidence of allergic conjunctivitis. The high occurrence of allergic conjunctivitis in the subject between 9-12 year (table 4) was because they get in contact with allergens in the environment as they play. The finding is in agreement with Gold and Peacock ${ }^{3}$, Duke ï Elder ${ }^{8}$, Frazier $^{1}$, Randolph and Moss ${ }^{2}$, Smolin and $\mathrm{O}^{\prime}$ Connor ${ }^{11}$, who said that allergic conjunctivitis is a disease more prevalent in childhood,

The seasonal manifestation of allergic conjunctivitis as seen in table 2 was attributed to dust and pollen in atmosphere. Gold and Peacock ${ }^{3}$, Coutu $^{12}$, Clifford ${ }^{9}$, Smolin and $\mathrm{O}^{\prime}$ Connor $^{11}$, Mcdowell $^{13}$, in their studies revealed the highest occurrence of allergic conjunctivitis during harmattan to be due to extreme cold and dust in the atmosphere.

There was high occurrence of allergic conjunctivitis in female than males (table 1) because of hormonal release. The socio-economic status background of a child was found to influence the occurrence of allergic conjunctivitis. Those with low nutritional status or from parents with low income had high frequency of this allergy as supported by Evans ${ }^{14}$, Randolph and Moss ${ }^{2}$, $\mathrm{Uddoh}^{15}$ due to poor hygiene common with people of that class. One therefore concludes that establishment of health services in the schools and reorientation of all parties involved (parents, teachers, health practitioners and government) will help in reducing the occurrence of allergic conjunctivitis.

TABLE 1: OCCURRENCE OF ALLERGIC CONJUNCTIVITIS BY GENDER

\begin{tabular}{|l|l|l|l|c|l|l|}
\hline & Male & \% of Male & Female & \% of Female & Total & \% Total \\
\hline Present & 48 & 32.0 & 89 & 59.3 & 137 & 91.3 \\
\hline Absent & 6 & 4.0 & 7 & 4.7 & 13 & $8.7 \%$ \\
\hline Total & 54 & 36.0 & 96 & 64.0 & 159 & $100 \%$ \\
\hline
\end{tabular}

TABLE 2: INFLUENCE OF CLIMATIC CONDITION ON THE OCCURRENCE OF ALLERGIC CONJUNCTIVITIS

\begin{tabular}{|l|l|l|}
\hline Seasons & NO. & Percentage \\
\hline Rainy season & 26 & $19.0 \%$ \\
\hline Harmattan & 67 & $48.9 \%$ \\
\hline Non-seasonal & 44 & $32.1 \%$ \\
\hline Total & 137 & $100 \%$ \\
\hline
\end{tabular}


TABLE 3: OCULAR FINDINGS ON EXTERNAL EXAMINATION

\begin{tabular}{|l|l|l|}
\hline Clinical Sign & $\begin{array}{l}\text { Pupils with History of } \\
\text { allergic conjunctivitis }\end{array}$ & Percentage \\
\hline Conjunctiva only & 93 & $67.9 \%$ \\
\hline Conjunctiva and eyelid only & 42 & $30.7 \%$ \\
\hline Conjunctiva, eyelid and cornea & 2 & $1.4 \%$ \\
\hline No clinical sign of Allergic conjunctivitis & Nil & Nil \\
\hline Total & 137 & $100 \%$ \\
\hline
\end{tabular}

TABLE 4: OCCURRENCE OF ALLERGIC CONJUNCTIVITIS BY AGE OF RESPONDENTS

\begin{tabular}{|l|l|l|}
\hline Age & NO & \% \\
\hline $5-8$ & 25 & $18.2 \%$ \\
\hline $9-12$ & 93 & $67.9 \%$ \\
\hline $13-16$ & 19 & $13.9 \%$ \\
\hline Total & 137 & $100 \%$ \\
\hline
\end{tabular}

TABLE 5: OCCUPATIONAL STATUS OF PARENTS OF RESPONDENTS

\begin{tabular}{|l|l|l|}
\hline Occupation & NO & \% \\
\hline Professional & 25 & $18.2 \%$ \\
\hline Civil servant & 35 & $25.6 \%$ \\
\hline Artisan & 77 & $56.2 \%$ \\
\hline Total & 137 & $100 \%$ \\
\hline
\end{tabular}

\section{R E F E R E N C E S}

1. Frazier, A. C. (1973): Allergy of the eye. Southern J. Opt, 15 (7): 11-8.

2. Randolph, G. T. and Moss, R. W. (1981): Allergies, Your Hidden enemy. Turnstone Press Limited, Wellingbrough Northampton shire, pp3-4.

3. Gold, E. R. and Peacock, D. P. (1970): Basin Immunology. John Wright and sons Limited, Bristol, 267pp.

4. Theodore, F. H. (1958): The treatment of ocular allergy. Am. J. Ophthalmol, 45:437-8.

5. Muir, M. (1979): Environmental factors and symptoms in infants at high risk of Allergy. J. Epidemiol. Com. Hlth, 43: 125-32.

6. Creer, C. H. (1979): Ocular pathology. Blackwell Scientific Publishers, pp94-5.

7. Buckley, J. R. (1988): Vernal conjunctivitis. Int. Ophthamol. Clin, 28(4):303-8.

8. Duke-Elder, S. (1970): Parson's diseases of the eye. $15^{\text {th }}$ Edn. The English Language book
Society, London, pp174-8.

9. Clifford R. F. (1983): The eye in General medicine. University Park Press, Baltimore, pp309-10.

10. Allansmith, M. R. and Ross, R. N. (1986): Ocular Allergy and mast cell stailizers. Surv. Ophthamol, 30 (4): 234-44.

11. Smolin, G. and O' Connor, G. R. (1986): Ocular Immunology. $2^{\text {nd }}$ Edn. Little Brown, Boston, pp157-8.

12. Coutu, R. B. (1991): Treatment of Vernal Keratoconjunctivitis ï A retrospective clinic case study. Opt. Vis. Sci. 68 (7): 561.

13. Mcdowe11, J. (1978): Epidemic Keratoconjunctivitis. Southern J. Opt. 20 (8): 8-10.

14. Evans, C. S. (1979): Combining Nutritional and Orthoptic therapy. The Optician, pp32-3.

15. Uddoh, C. K. (1988): Nutrition. Macmillan Publishers, 96pp. 